\title{
Effects of river damming in Neotropical piscivorous and omnivorous fish: feeding, body condition and abundances
}

\author{
Larissa Strictar Pereira ${ }^{1}$, Angelo Antonio Agostinho ${ }^{2}$ and Rosilene Luciana Delariva ${ }^{3}$
}

\begin{abstract}
The increase in abundance of small-sized fishes is common after a reservoir is formed. There is an increase in the consumption of fish, from typically piscivorous fish to opportunistic species that take advantage of abundant resources. This study aims to evaluate the effects of diet changes induced by damming on the feeding activity and condition factor of typically piscivorous (Hoplias aff. malabaricus and Oligosarcus longirostris) and opportunistic (Astyanax lacustris (ex Astyanax altiparanae) and Pimelodus britskii). Sampling was conducted before and after the impoundment in the Iguaçu River in the region of Salto Caxias, Paraná State, Brazil. Stomach contents were analysed by the volumetric method. Feeding activity and body condition were inferred by the mean stomach repletion index and the mean condition factor. Typically piscivorous species presented a general tendency of decreased feeding activity and increased condition factor, while opportunistic species, presented a decrease in condition and feeding activity in the most affected sites. The increase in the condition factor of piscivorous fish suggests that these species benefit by the increased abundance of small size prey fish. Some opportunist species that do not have adjustments for the piscivorous diet, regardless of the intensity of consumption and resource availability, can suffer negative reflex when adopting a piscivorous diet.

O aumento na abundância de peixes de pequeno porte é comum logo após a formação de um reservatório, levando a um aumento no consumo de peixes, tanto por peixes piscívoros como oportunistas que se aproveitam do recurso abundante. Esse estudo visa avaliar os efeitos da mudança de dieta induzida pelo represamento na atividade alimentar e condição nutricional, tanto de espécies piscívoras (Hoplias aff. malabaricus e Oligosarcus longirostris) quanto de espécies oportunistas (Astyanax lacustris (ex Astyanax altiparanae) e Pimelodus britskii). Para tanto, foram realizadas amostragens nas fases pré e pós-represamento no rio Iguaçu na região de Salto Caxias, Paraná, Brasil. Os conteúdos estomacais foram avaliados pelo método volumétrico. A atividade alimentar foi determinada pelo índice de repleção estomacal e a condição nutricional através do fator de condição relativo. As espécies tipicamente piscívoras apresentaram, em geral, incremento no fator de condição e queda na atividade alimentar e a espécie mais oportunista apresentou queda no fator de condição e índice de repleção nas regiões mais afetadas pelo represamento. O aumento no fator de condição de espécies piscívoras sugere que estas se beneficiam pelo aumento de abundância das espécies de pequeno porte. Enquanto espécies que não possuem adaptações para uma dieta piscívora, independente da intensidade de consumo e disponibilidade desse recurso, podem sofrer reflexos negativos em sua condição nutricional, em detrimento da ausência de pré-adaptações à piscivoria.
\end{abstract}

Keywords: Condition factor, Feeding activity, Opportunist diet, Piscivory, Reservoir.

\section{Introduction}

Piscivorous fish impact the aquatic community and water quality (Nowlin et al., 2006) contributing to the stabilisation of food webs (Rooney et al., 2006). Predators may have large impacts on ecological systems as they remove vulnerable organisms from the environment (Lima, 1998).When a predator's foraging behaviour shifts, it can affect the stability of predatorprey population dynamics (DeAngelis et al., 1975), spatial distribution of predators (Van Der Meer \& Ens, 1997), food chain length (Schmitz, 1992) and the strength of species interactions in complex food webs (Novak \& Wootton 2008).

\footnotetext{
${ }^{1}$ Programa de Pós-Graduação em Ecologia de Ambientes Aquáticos Continentais (PEA), Departamento de Biologia (DBI), Universidade Estadual de Maringá, Av. Colombo 5790, 87020-900 Maringá, PR, Brazil. lari.strictar@gmail.com (corresponding author)

${ }^{2}$ Núcleo de Pesquisas em Limnologia, Ictiologia e Aquicultura (Nupélia), PEA, DBI, Universidade Estadual de Maringá, Av. Colombo 5790, 87020-900 Maringá, PR, Brazil. agostinhoaa@nupelia.uem.br

${ }^{3}$ Universidade Estadual do Oeste do Paraná, Centro de Ciências Biológicas e da Saúde. Rua Universitária 2069, Caixa Postal 711, 85819110 Cascavel, PR, Brazil. rosilene.delariva@unioeste.br
} 
The formation of reservoirs leads to deep structural changes in fish communities in relation to the original fluvial system. After damming, most rheophilic species disappear and those that persist are confined upstream and in the mouth of tributaries, where the habitat conditions are more similar to the original (Agostinho et al., 2008). The new environment is colonised largely by those species with pre-adaptations for the lentic condition (Fernando \& Holcik, 1991) and those with opportunistic strategies. Dominant species in a new reservoir are small-sized, with feeding plasticity, low longevity and high reproductive performance (opportunist strategy, sensu Winemiller, 1989), denoting advantages in the colonisation process (Agostinho et al., 1999). This small sized species become an abundant resource and explains the success of piscivores after impoundments (Luz-Agostinho et al., 2006; Hahn \& Fugi, 2007; Bennemann et al., 2011).

Extensive incorporation of allochthonous material, as invertebrates and plants, during the reservoir filling provides an important contribution of food resources for fish (Loureiro-Crippa \& Hahn, 2006). The high availability of allochthonous resource in the environment, may cause a positive effect in the production of all trophic levels, an event known as the trophic upsurge period (Kimmel \& Groeger, 1986; O’Brien, 1990; Gubiani et al., 2011). The high availability of small body size species in the new environment should increase the frequency of fish with a carnivorous fish diet (Novakowski et al., 2007) or even lead some omnivorous species to piscivory (Luz-Agostinho et al., 2006; Delariva et al., 2007). Although the nutritional quality of a fish-based diet should be higher than one based on other items, such as invertebrates, due to its high protein (Anthony et al., 2000) and energy content (Davis et al., 1998), the organism's response to this consumption should differ according to the species diet in the natural environment. Typically piscivorous species have preadaptations, both morphological (body size, position and size of the mouth opening, adaptations in the digestive tract) and behavioural (capture strategies of prey) (ZavalaCamim, 1996), that provides a greater profit by consuming this abundant resource after the damming than among the less specialized, that consume opportunistically.

An efficient way to determine the energy intake of an individual is the condition factor, which reflects the recent nutritional status of the fish and the expenditure of reserves in activity (Vazzoler, 1996). Such methodology has been used by several authors to describe the impacts of reservoir formation in fish assemblages (Gubiani et al., 2009; Pacheco et al., 2009; Abelha et al., 2012; Orsi \& Britton, 2014). The condition factor expresses individual wellbeing with respect to the environment and it compensates for changes in the form or condition with length (Le Cren, 1951). This index can be used to indicate whether an individual is in better or worse condition than others of the same length (Árnason et al., 2009). It also provides valuable information for the understanding of species ecology, as they reflect the prevailing environmental conditions (Abelha et al., 2012).

Thus, it is expected that the increase in the abundance of small sized fish should lead to an increase in piscivory and in the nutritional status of fish with pre adaptations to piscivory. In this context, the present study aims to evaluate changes in abundance, as well as in diet and its effect on the nutritional state of the species that presented a piscivorous diet during the first year after Salto Caxias Reservoir formation. The hypothesis is that changes occur in the nutritional status and species that were essentially piscivorus before the impoundment should have higher energy gain in relation to those species in which fish become important in the diet only after damming.

\section{Material and Methods}

Sampling. Was carried out before and after the Salto Caxias Reservoir filling, located in Iguaçu River $\left(25^{\circ} 32^{\prime} 35^{\prime \prime} \mathrm{S} / 53^{\circ} 29^{\prime} 43^{\prime \prime} \mathrm{W}\right)$ and closed in October 1998. Samples were taken quarterly before damming from March 1997 to February 1998, and after the closure of the dam from April 1999 to January 2000.

The 14 sampled sites were selected according to their position in respect to the dam. Including five sites located on tributaries of Iguaçu River 10 to $20 \mathrm{~km}$ upstream from their mouth (TU - tributaries upper sections not affected by the reservoir), and five sites in lower sections flooded by the reservoir (TL - tributaries lower sections) in each of the considered tributaries. In addition, there were two sites upstream from the main river (Iguaçu River - UP), one site in the reservoir (RE) and one downstream from the dam (DO) (Fig. 1). It is important to highlight that all sites suffered direct or indirect impacts due to damming, or in a lesser extent, as in the upstream and tributaries upper section areas, or greater as in dam and downstream areas.

Samples were taken using gillnets (mesh sizes ranging from 3.0 to $16.0 \mathrm{~cm}$ between opposite knots, 12 simple gillnets and 3 trammel nets) operated for $24 \mathrm{~h}$ and checked every $8 \mathrm{~h}$.

Laboratory procedures. Fish were identified by taxonomists and vouchers specimens were deposited in the Fish Collection of Nupélia (UEM/Maringá/Numbers: NUP 2452, NUP 687, NUP 721, NUP 1786). After identification, specimens were measured (total and standard length), weighed (total weight) and gutted; stomachs containing food were fixed in $4 \%$ formalin and later transferred to ethanol $70 \%$. The stomach contents were examined to identify food items under a stereomicroscope and optical microscope. The contents were measured by the volumetric method (Hyslop, 1980; Ahlbeck et al., 2012): the total volume of a food item taken by the fish population is given as a percentage of the total volume of all stomachs contents, estimated using graduated test tubes and a glass counting plate (Hellawell \& Abel, 1971). 


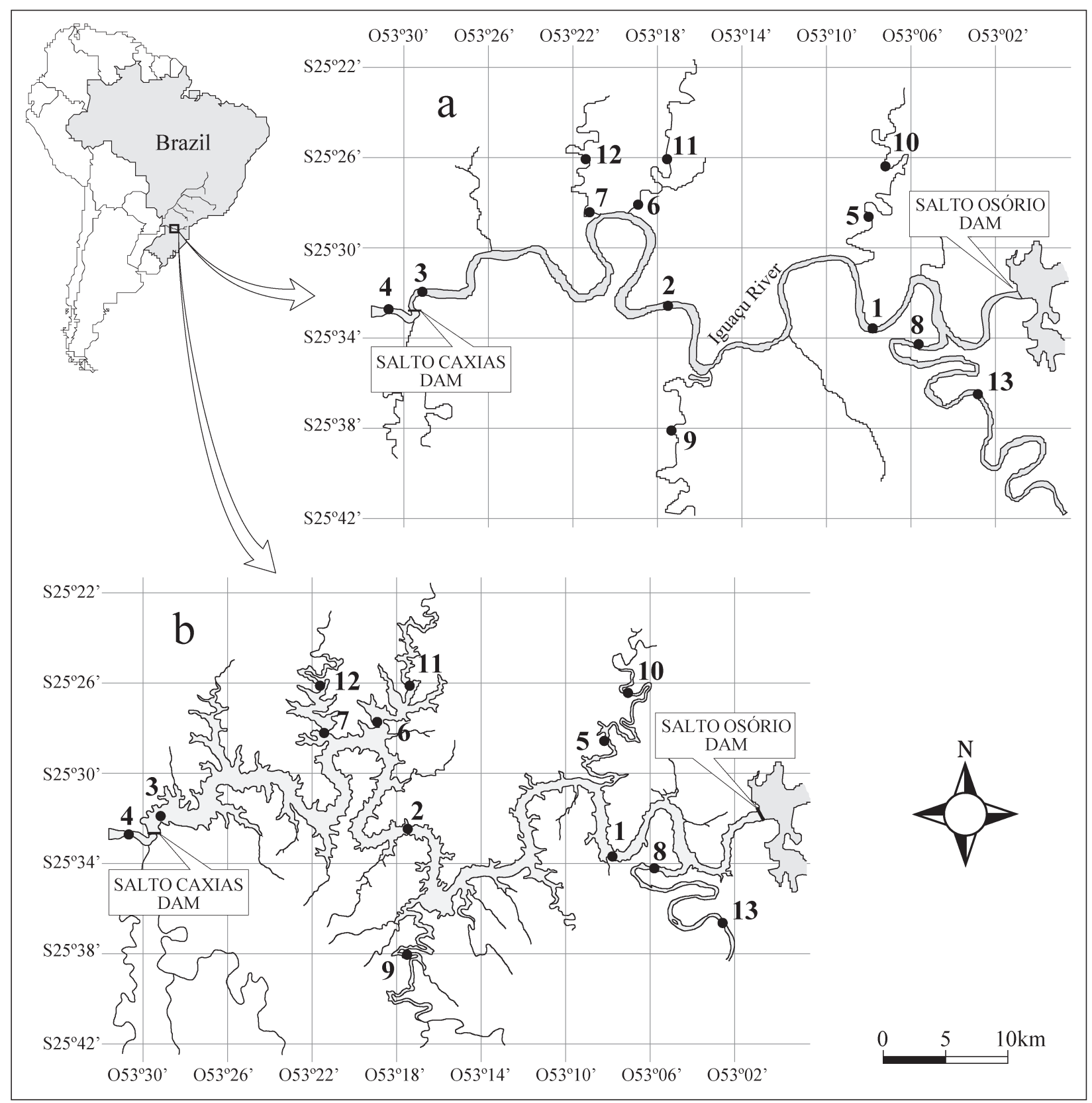

Fig. 1. Location of the sample stations in the Iguaçu River and the dam influence area. a) Before damming. b) After damming. [Point 1-2 = upstream from the Iguaçu river (UP); point $3=$ reservoir region (RE); point $4=$ downstream (DO); 5-9 = tributaries low section (TL); 10-14= tributaries upper section (TU)].

Data analysis. The chosen species were Astyanax lacustris (Lütken, 1875) (ex Astyanax altiparanae Garutti \& Britski, 2000 (Lucena \& Soares, 2016)), Hoplias aff. malabaricus, Oligosarcus longirostris Menezes \& Géry, 1983 and Pimelodus britskii Garavello \& Shibatta, 2007, all of which were selected on the basis of their abundance and feeding habits. Astyanax lacustris and $P$. britskii as opportunistic species and $H$. aff. malabaricus and $O$. longirostris as tipically piscivorous.

The fish abundance was indexed as catch per unit effort (CPUE), estimated by the ratio between the number of individuals collected by day and the area of the nets used in the sampling, multiplied by 1000 (unit: number of individuals $/ 1000 \mathrm{~m}^{2}$ net set for $24 \mathrm{~h}$ ). To evaluate the differences in the species abundance before and after damming, a nonparametric Scheirer-Ray-Hare test (Dytham, 2011) was applied to the data. Period (before and after damming) and sites were used as factor and the CPUE as the dependent variable.

Possible differences in species diet before and after damming were evaluated by a Permutational Multivariate Analysis of Variance (Permanova, Anderson, 2006) using period and sites as factor and diet data, $\log +1$ transformed, as dependent variable. 
Food items were pooled into broader categories, named detritus/sediment (particulate organic matter in different stages of decomposition and with mineral particles present), algae (filamentous and unicellular), plants (fruit, seeds and leaves of vascular plants and bryophytes), insects (Coleoptera, Diptera, Ephemeroptera, Hemiptera, Hymenoptera, Isoptera, Megaloptera, Odonata, Orthoptera, Plecoptera and Thichoptera), microcrustaceans (Copepoda and Cladocera, especially planktonic species), macroinvertebrates (Arachnida, Bivalvia, Gastropoda, Annelida and Diplopoda), microinvertebrates (Testacea, Porifera, Rotifera, bryozoa, Nematoda and Ostracoda) and fish (identified to the lowest taxonomic level possible).

The nutritional status was given by the relative condition factor (K; Le Cren, 1951) and the feeding activity was determined using averages of the repletion index (RI). The repletion index (RI) was estimated for each individual through the relative contribution of stomach weight (We) to total weight (Wt) $(\mathrm{RI}=\mathrm{We} / \mathrm{Wt} \times \mathrm{100})$. Each of these index estimated the nutritional state of the individuals in different time scales; repletion index estimates the amount of food ingested in a short temporal scale and the condition factor represents the nutritional state of an individual in a larger scale. Finally, the degree of changes in the feeding habit was based on the volumetric proportion of fish included in the diet (piscivory) in each period.

Variations in the condition factor were evaluated for each individual based on the relative condition means, which were calculated using the equation: $\mathrm{K}=\mathrm{Wt} / \mathrm{Wt}$ ', where $\mathrm{Wt}$ is the individual weight and $\mathrm{Wt}^{\mathrm{t}}$ is the estimated weight based on the standard length (Ls) and weight relationship. The Wt' represents the expected weight that a fish with a determined Ls is expected to possess, instead of the observed weight (Wt) (Le Cren, 1951).

The parameters of the Ls $\times$ Wt relationship, needed to estimate the condition factor, considered all individuals captured for each species. Differences between the sexes were tested using analysis of covariance (ANCOVA), with weight as the dependent variable, length as the predictive variable and sex as the covariate; if differences between sexes were significant, the relationship Ls $\mathrm{x}$ Wt was estimated for each sex separated and, after the condition factor was obtained, they were grouped for analysis. The standard length and weight data were log-transformed for fitting in the test assumptions. To reduce the effect of those less represented length classes, the analyzes were performed for the length class covering the largest possible number of adults (Gomes \& Agostinho, 1997), by this, analyses were performed for a pre determined class size, after the elimination of young and very small/large adult individuals that did not present sampling sufficiency.

The degree of piscivory was obtained as the percentage of volume of fish consumed in total diet. Also, to evaluate whether the variations in the nutritional condition were directly related to these changes in the feeding habit (piscivory), a Pearson correlation was applied to the percentage of fish consumed in total diet by each species for period and the condition factor of each analysed species (Dytham, 2011). To test possible differences in the condition factor and the repletion index between periods and sites, a factorial analysis of variance (ANOVA) was applied to both variables, with period (before and after damming) and sampling sites (downstream, reservoir, upstream, tributaries lower section and tributaries upper section) being used as factors. Finally, to evaluate if changes in the condition factor are related to the amount of ingested food or if it is related to other environmental changes, a Pearson correlation between repletion index and condition factor was applied.

The statistical tests were performed with the $\mathrm{R}$ Programming Environment (The R Project for Statistical Computing, http://www.r-project.org/) using the Vegan package (Oksanen et al., 2015) and the graphics in Statistica Statsoft 10 (StatSoft Inc., 2011).

\section{Results}

All species considered in this study presented significant increases in abundance (CPUE), after damming. The Scheirer-Ray-Hare test detected significant interaction for sites and periods for all species, except $P$. brtskii that presented significant differences for sites and periods (Table 1). The studied species that had a greater increase in the general abundance (CPUE) was A. lacustris, with an abundance (CPUE) 30 times higher in the period after damming than the period before damming. Hoplias aff. malabaricus and $O$. longirostris presented, in average, an increase in abundance (CPUE) four times higher than the period before damming. Pimelodus britskii abundance (CPUE) was the one that showed less increase in the after damming period, only two times the abundance (CPUE) of the before damming period.

Table 1. Scheirer-Ray-Hare test and Permutational Multivariate Analysis of Variance applied to abundance (CPUE) and diet, respectively, for sites and periods for the analysed species in the Iguaçu River and its tributaries, in the Salto Caxias Reservoir region.

\begin{tabular}{|c|c|c|c|c|c|}
\hline \multirow{2}{*}{ Species } & \multirow{2}{*}{ Factor } & \multicolumn{2}{|c|}{ Abundance (CPUE) } & \multicolumn{2}{|c|}{ Diet } \\
\hline & & SHR & $\mathrm{p}$ & pseudo-F & $\mathrm{p}$ \\
\hline \multirow{3}{*}{ A. lacustris } & Site & 17.35 & $<0.001$ & 0.0535 & 0.001 \\
\hline & Period & 12.29 & $<0.001$ & 0.0154 & 0.011 \\
\hline & Site*Period & 6.02 & 0.014 & 0.01727 & 0.005 \\
\hline \multirow{3}{*}{$H$. aff. malabaricus } & Site & 9.84 & 0.001 & 0.03306 & 0.001 \\
\hline & Period & 13.03 & 0.003 & 0.03828 & 0.001 \\
\hline & Site*Period & 4.71 & 0.029 & 0.02865 & 0.001 \\
\hline \multirow{3}{*}{ O. longirostris } & Site & 18.5 & $<0.001$ & 0.02172 & 0.001 \\
\hline & Period & 2.7 & 0.09 & 0.03415 & 0.001 \\
\hline & Site*Period & 7.99 & 0.004 & 0.02431 & 0.001 \\
\hline \multirow{3}{*}{ P. britskii } & Site & 5.22 & 0.022 & 0.03278 & 0.001 \\
\hline & Period & 24.59 & $<0.001$ & 0.02026 & 0.001 \\
\hline & Site*Period & 3.24 & 0.07 & 0.01253 & 0.001 \\
\hline
\end{tabular}


When considering sites $H$. aff. malabaricus presented a higher increase after damming in the downstream and lower tributaries regions, $O$. longirostris in the downstream, reservoir and upstream sites and A. lacustris and P. britskii in the reservoir and downstream sites. The abundance (CPUE) of fish species used as prey increased especially in the downstream and reservoir sites (Fig. 2).

All species presented significant differences in diet after damming according to site (Table 1). Before the impoundment, A. lacustris consumed high proportions of plants and very low proportions of fish (only fish scales). After the dam closing, this species also consumed large amounts of fish, mainly in reservoir areas and downstream the dam (Table 2). Fish consumed by this species could not be identified because they consisted only of partially digested fragments (fish pieces) and fish scales. Hoplias aff. malabaricus presented a diet exclusively based on fish in both periods, with a notable exchange of Ciclidae by Curimatidae (Cyphocharax cf. santacatarinae - Table 3). Oligosarcus longirostris and $P$. britskii, showed diets based mainly on insects and fish before damming, and exhibited a diet essentially based on fish in the period after damming (Table 2).
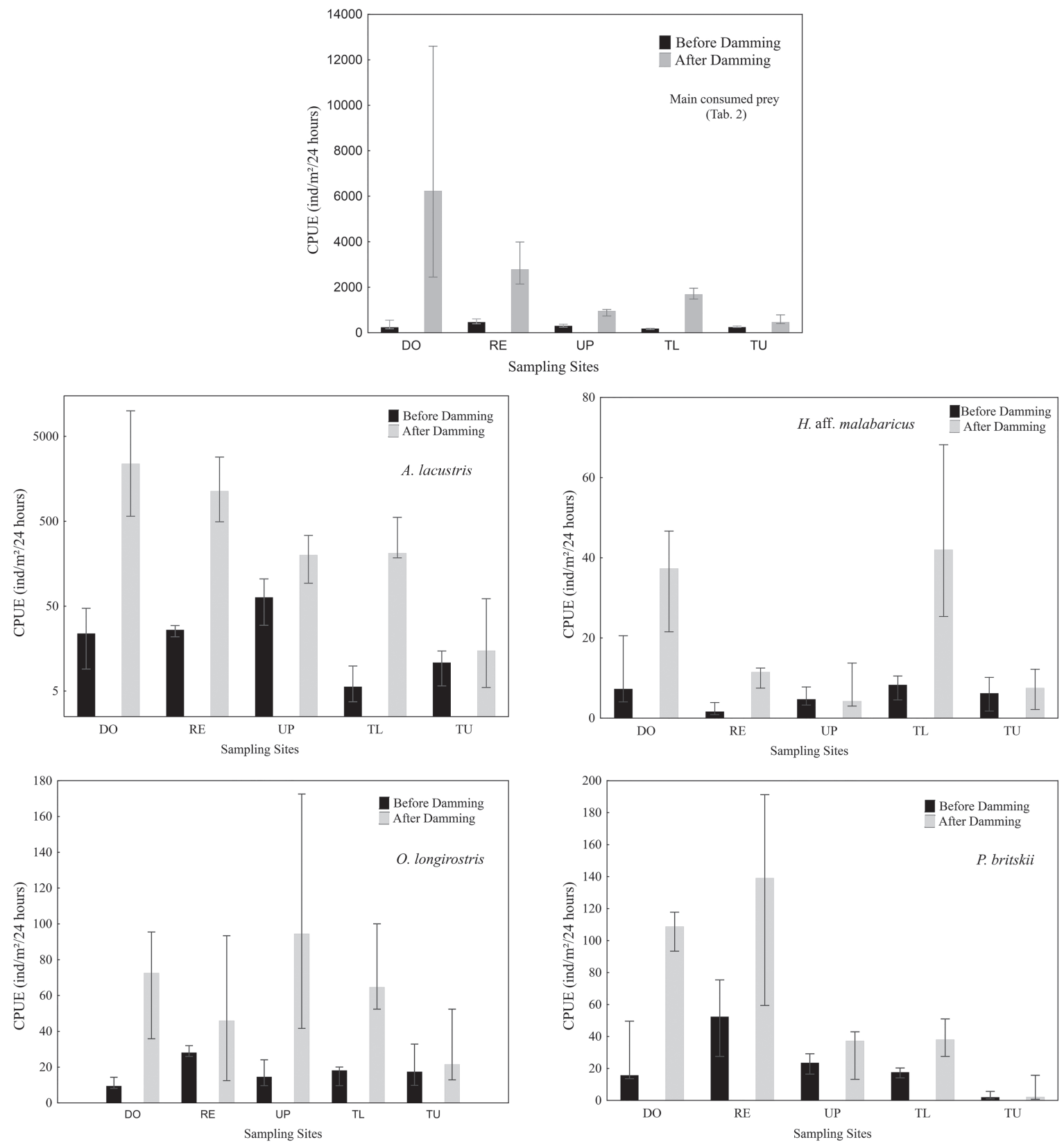

Fig. 2. Median abundance (Capture per unit effort - CPUE; unit: number of individuals $/ 1,000 \mathrm{~m}^{2}$ of nets set for $24 \mathrm{~h}$ ) of the most consumed prey and analysed species from Iguaçu River in the Salto Caxias Reservoir area of influence, before and after damming (RE - reservoir region; DO - downstream; UP - upstream from the Iguaçu River; TL - tributaries lower section; TU - tributaries upper section). Vertical bars=Min and Max values. 


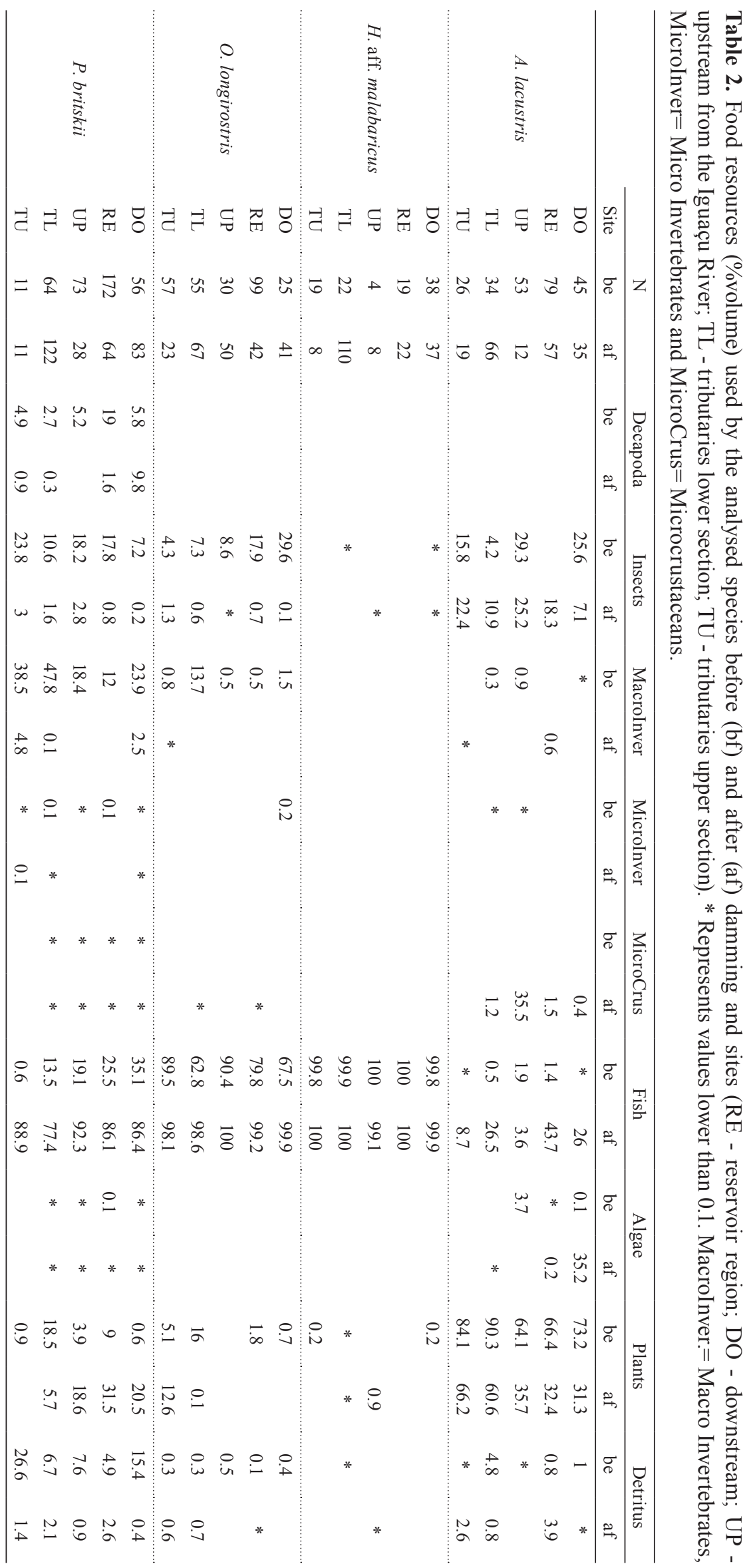




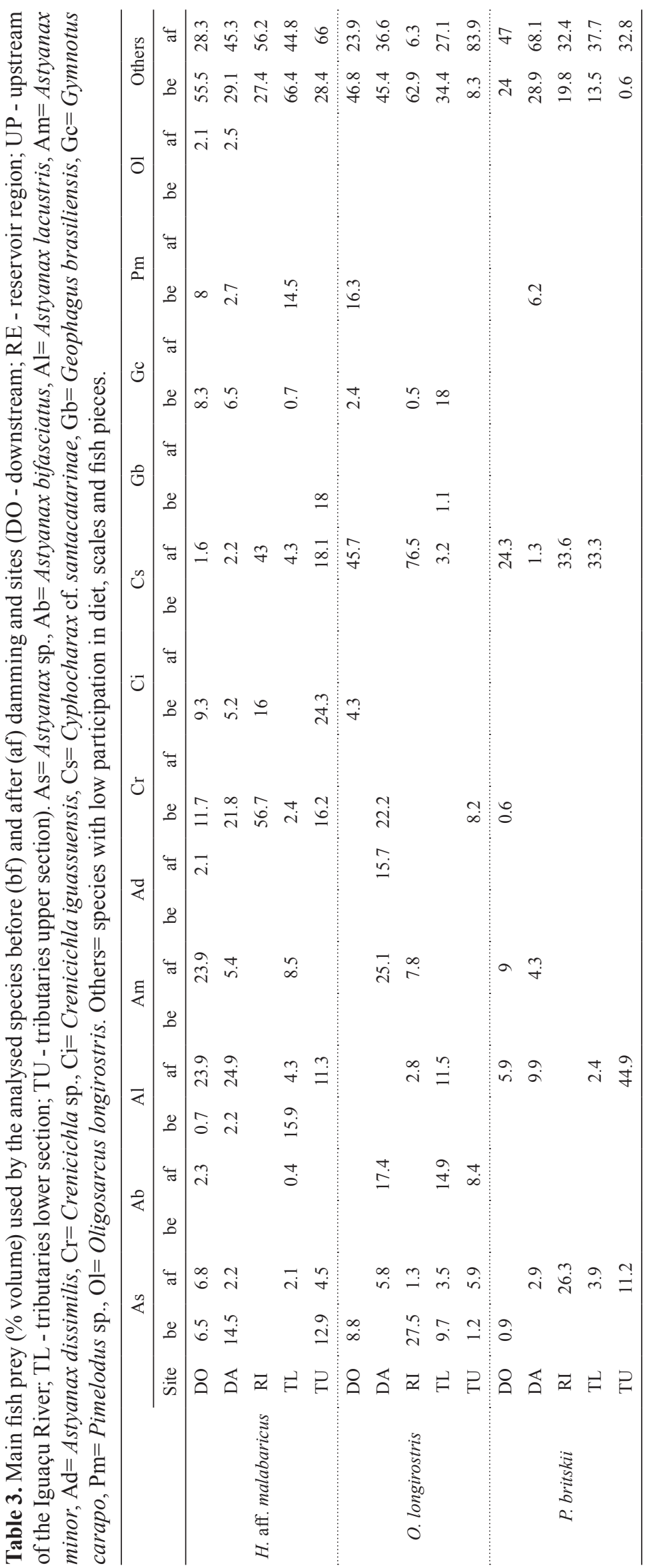


Astyanax lacustris and O. longirostris were the only species showing differences among sexes in the length weight relationship (Table 4). The estimated weights, necessary for the calculation of $\mathrm{K}$, were obtained by the equations showed in Table 4.

Astyanax lacustris was the unique species presenting negative and significant correlation between the piscivory and condition factor $(\mathrm{r}=-0.46, \mathrm{p}=0.006)$. Oligosarcus longirostris and $P$. britskii presented a positive significant correlation between the fish consumption and the condition factor $(\mathrm{r}=0.44, \mathrm{p}=0.007$ and $\mathrm{r}=0.60, \mathrm{p}<0.0001$, respectively), while for $H$. aff. malabaricus, it was not significant $(\mathrm{r}=0.14$, $\mathrm{p}=0.40$ ) (Fig. 3).

The ANOVA detected significant interaction in the condition factor and the repletion index for sites and periods only for A. lacustris and P. britskii. For $H$. aff. malabaricus ANOVA detected significant differences in the condition factor and repletion index for sites and periods while $O$. longirostris presented significant difference only for sites (Table 5).

The condition factor of all species increased after the reservoir formation, with the exception of A. lacustris, which decreased in the reservoir and downstream areas (Fig. 4). In all four species repletion index decreased in the lentic sites (RE and TL), while A. lacustris increased in the downstream sites. Hoplias aff. malabaricus presented a reduction in the repletion index in the downstream site, while for $O$. longirostris and $P$. britskii, the values were less affected (Fig. 4). The Pearson correlation index detected a positive significant correlation between the condition factor

Table 4. Length-weight relationship and covariance analysis results for the analysed species in the Iguaçu River and its tributaries, in the Salto Caxias Reservoir region. n-Number of analyzed individuals for the condition factor and repletion index. Min-Minimum standard length $(\mathrm{cm})$ and Max-Maximum standard length $(\mathrm{cm})$.

\begin{tabular}{|c|c|c|c|c|c|c|c|c|}
\hline Species & $\mathrm{n}$ Before & n After & $\min$ & $\max$ & Sex & Equation & $\mathrm{F}$ & $\mathrm{p}$ \\
\hline \multirow{2}{*}{ A. lacustris } & \multirow{2}{*}{1459} & \multirow{2}{*}{8976} & \multirow{2}{*}{5,1} & \multirow{2}{*}{9,4} & Male & $\mathrm{Wt}=0.028 * \mathrm{Ls}^{2.78}$ & \multirow{2}{*}{136,3} & \multirow{2}{*}{$<0.001$} \\
\hline & & & & & Female & $\mathrm{Wt}=0.037 * \mathrm{Ls}^{2.95}$ & & \\
\hline H. aff. malabaricus & 341 & 921 & 19,7 & 31,4 & - & $\mathrm{Wt}=0.013 * \mathrm{Ls}^{3.068}$ & 1,44 & 0,23 \\
\hline \multirow{2}{*}{ O. longirostris } & \multirow{2}{*}{887} & \multirow{2}{*}{768} & \multirow{2}{*}{11,3} & \multirow{2}{*}{21,7} & Male & $\mathrm{Wt}=0.012 * \mathrm{Ls}^{3.07}$ & \multirow{2}{*}{21,2} & \multirow{2}{*}{$<0.001$} \\
\hline & & & & & Female & $\mathrm{Wt}=0.014 * \mathrm{Ls}^{3.12}$ & & \\
\hline P. britskii & 1305 & 1835 & 15,3 & 27,9 & - & $\mathrm{Wt}=0.014 * \mathrm{Ls}^{3.11}$ & 1,5 & 0,21 \\
\hline
\end{tabular}
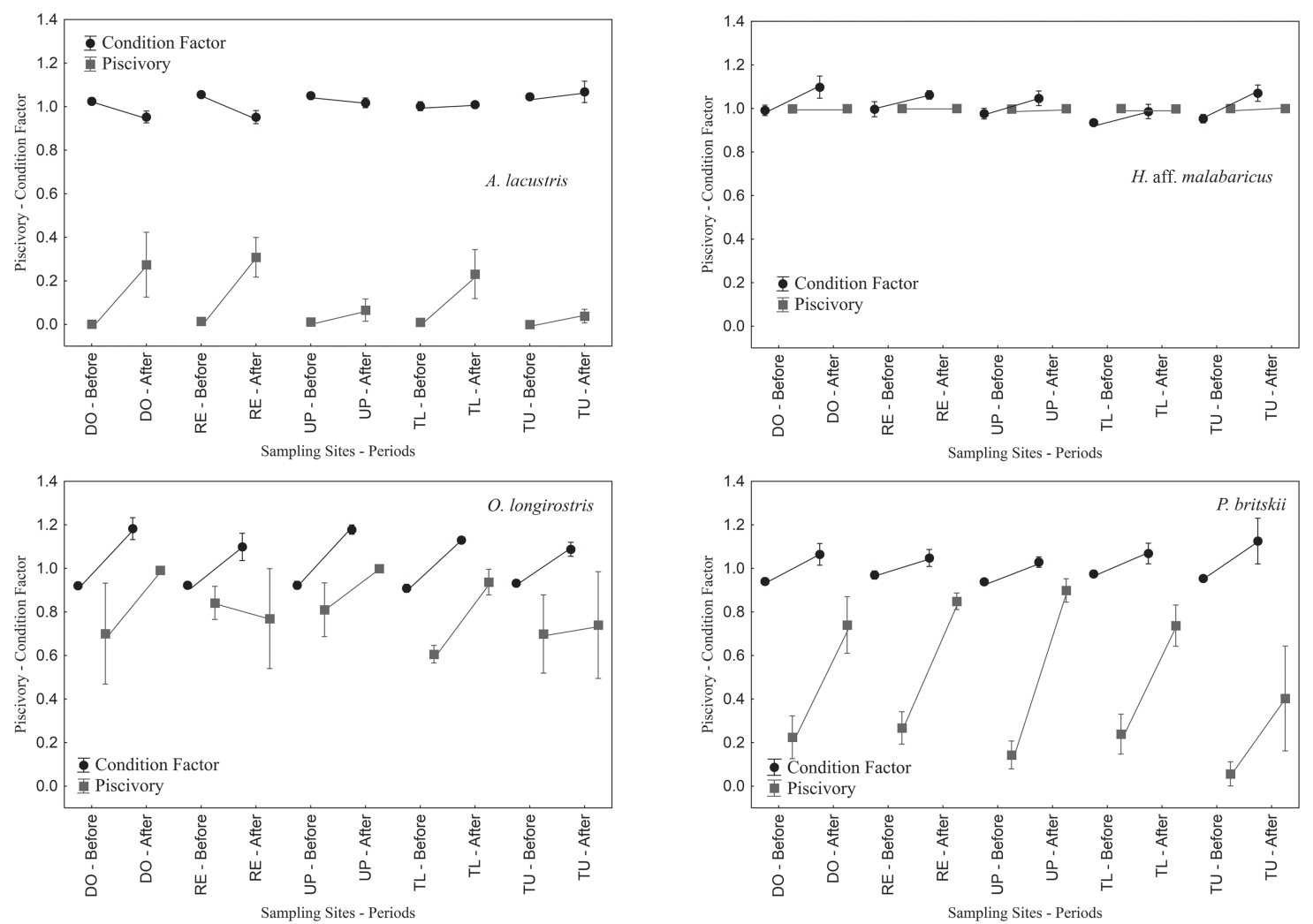

Fig. 3. Piscivory (\%) and mean condition factor of the analysed species from Iguaçu River in the Salto Caxias Reservoir influence, before and after damming and sites (RE - reservoir region; DO - downstream; UP - upstream from the Iguaçu River; TL - tributaries lower section; TU - tributaries upper section). Vertical bars= standard error. 
and the repletion index for $A$. lacustris, $H$. aff. malabaricus and $O$. longirostris $(\mathrm{r}=0.3, \mathrm{p}<0.001, \mathrm{r}=0.15, \mathrm{p}<0.001$ and $\mathrm{r}=-0.05, \mathrm{p}=0.029$ respectively). Pimelodus britskii, the correlation was not significant $(\mathrm{r}=0.24, \mathrm{p}=0.16)$.

Table 5. Analysis of Variance applied to the condition factor $(\mathrm{K})$ and repletion index (RI) values for sites and periods for the analysed species in the Iguaçu River and its tributaries, in the Salto Caxias Reservoir region.

\begin{tabular}{|c|c|c|c|c|c|}
\hline \multirow{2}{*}{ Species } & \multirow{2}{*}{ Factor } & \multicolumn{2}{|c|}{$\mathrm{K}$} & \multicolumn{2}{|c|}{ RI } \\
\hline & & $\mathrm{F}$ & $\mathrm{p}$ & $\mathrm{F}$ & $\mathrm{p}$ \\
\hline \multirow{3}{*}{ A. lacustris } & Site & 22.13 & $<0.001$ & 18.04 & $<0.001$ \\
\hline & Period & 61.72 & $<0.001$ & 25.03 & $<0.001$ \\
\hline & Site*Period & 4.52 & 0.003 & 30.03 & $<0.001$ \\
\hline \multirow{3}{*}{ H. aff. malabaricus } & Site & 9.74 & $<0.001$ & 1.08 & 0.36 \\
\hline & Period & 46.53 & $<0.001$ & 4 & 0.04 \\
\hline & Site*Period & 1.7 & 0.14 & 0.3 & 0.87 \\
\hline \multirow{3}{*}{ O. longirostris } & Site & 9.41 & $<0.001$ & 0.31 & 0.86 \\
\hline & Period & 377.6 & $<0.001$ & 124.18 & $<0.001$ \\
\hline & Site*Period & 11.46 & $<0.001$ & 11.3 & $<0.001$ \\
\hline \multirow{3}{*}{ P. britskii } & Site & 4.35 & $<0.001$ & 8.08 & $<0.001$ \\
\hline & Period & 347.7 & $<0.001$ & 162.8 & $<0.001$ \\
\hline & Site*Period & 1.24 & 0.28 & 43.63 & $<0.001$ \\
\hline
\end{tabular}
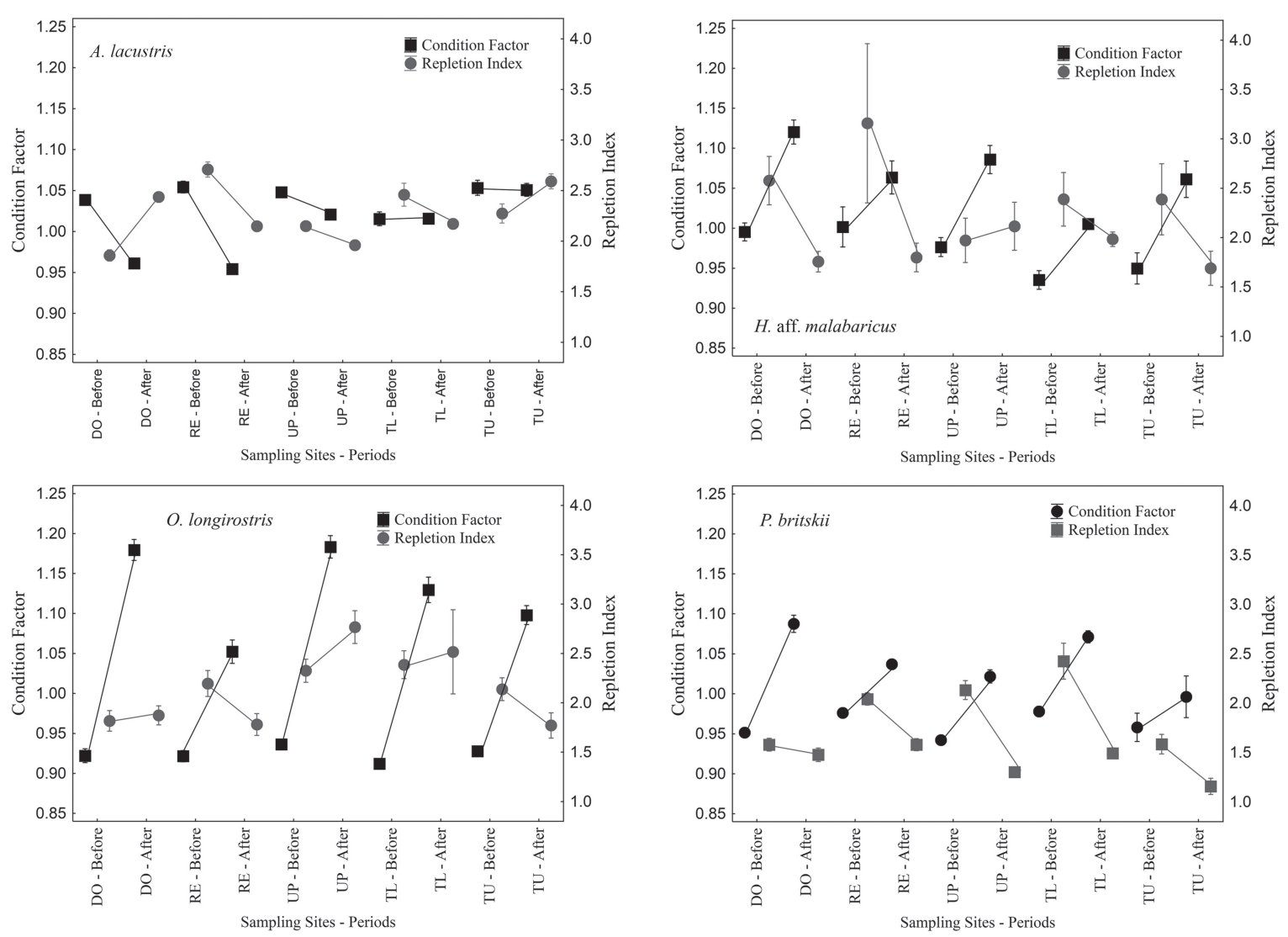

Fig. 4. Repletion Index (righ) and condition factor (left) of the analysed species from Iguaçu River in the Salto Caxias Reservoir influence, before and after damming and sites (RE - reservoir region; DO - downstream; UP - upstream from the Iguaçu River; TL - tributaries lower section; TU - tributaries upper section). Vertical bars= standard error.

Proliferation of small-sized fish during the first years after damming and the increase in the prey availability was a clear tendency observed in this study. In response to the increase in prey availability an increase in the piscivorous abundance was observed. Similar patterns have been reported for other reservoirs (Agostinho et al., 1999; Luz-Agostinho et al., 2006; Bennemann et al., 2011). This was also observed in the present study as the sites that presented the higher increases in prey abundance (DO and RE) also presented the higher increases in piscivorous abundance, as observed for $H$. aff. malabaricus and $O$. longirostris, specialist piscivorous (Hahn \& Fugi, 2008), that do not change their diet despite environmental changes, and for $A$. lacustris and $P$. britskii (opportunist piscivorous), in which the fish consumption was sporadic or even inexistent (Cassemiro et al., 2005; Luz-Agostinho et al., 2006). This increase in specialist piscivorous abundance can be due to the increase in prey availability, that is highlighted by the great participation of forage species as Astyanax dissimilis, Crenicichla spp. and Cyphocharax cf. santacatarinae, in piscivorous species diet after damming. 
Hahn \& Fugi (2008) verified that some species eat fish parts after a reservoir is formed, these authors also highlight that species that do not possess the ability of taking away prey parts, due to the lack of morphological adaptations for a piscivorous diet, are characterized as necrophagous. As A. lacustris lacks morphological treats that would allow it to pursue, capture and kill fish, the great participation of fish found in this species diet would be an indicative that this species is feeding of dead fish fragments or fish scales, and, if this is true, this species presents a necrophagous behaviour. This hypothesis is, however, based on speculation and as such must be confirmed by more accurate observation of feeding behaviour.

On the other hand, the increase in fish consumption by P. britskii, seems to be connected to ontogenetic changes, with adults more inclined to consume fish than young (Delariva et al., 2007) and not only to the necrofagous behaviour. Such hypothesis is enhanced by the fact that, after damming, larger individuals were captured in the dam sites and presented a piscivorous diet with great participation of Cyphocharax cf. santacatarinae. This fact highlights the opportunistic behaviour of $P$. britskii as it fed in the most available prey in the environment.

In dammed rivers, changing in the diet composition can be associated to changes in feeding resources availability and to the species ability to explore these resources in the novel environment. The feeding plasticity in Neotropical fish has been shown for a great number of species (Hahn et al., 1998; Abelha et al., 2001; Luz-Agostinho et al., 2006). Thus, fish respond to the low availability of preferential resources by changing its behaviour to consume different items as the preferential ones become scarce (Dill, 1983). All species presented an increase in the condition factor, with the exception of $A$. lacustris, especially in those sites that were more influenced by the impoundment (RE) or by flow control (DO) independent of changes in the feeding activity. In A. lacustris, the change from a predominantly herbivorous diet to a piscivorous one occurred in different intensities between sites, being more relevant in the reservoir region (RE) and downstream stretches (DO) and less pronounced in the upstream site (UP). The fact that this species showed more pronounced changes in diet composition (herbivory to piscivory) and presented a high decrease in the condition factor suggests that changes in diet composition can have a negative effect on the body condition even when high resource consumption rates are observed.

Hoplias aff. malabaricus and $O$. longirostris usually swallow their prey whole (Casatti et al., 2001; Peretti \& Andrian, 2008) requiring them to feed less often (Nikolsky, 1963) resulting in low feeding activity. Increased condition factor, despite the decrease in repletion index, might be connected to the lower energetic cost to the capture, manipulation and digestion of the prey, as suggested by the availability of small-sized fish and morpho-physiological adaptations to piscivory.
The fact that $A$. lacustris and $P$. britskii, both opportunistic species, presented different responses in the condition factor with a piscivorous diet, is related with differences in morphology traits between the two species. Pimelodus present a very wide mouth opening, ability of store large amount of food in the stomach and histological adaptations to piscivory (Santos et al., 2007; Hahn \& Fugi, 2008; Peretti \& Andrian, 2008). These features allow eliciting the piscivorous behaviour by such species (Hahn \& Fugi, 2008) providing better energy use and increase in the condition factor. On the other hand, A. lacustris present terminal and small mouth, delicate stomach and longer intestine (Peretti et al., 2008) associated with a more omnivorous diet specialized for small food items, like algae and insects.

Astyanax lacustris abundance grew thirty times more after damming. This high density combined with the presence of other four abundant Astyanax species (Baumgartner et al., 2012) that also fed mostly of plants before damming (Cassemiro et al., 2005; Delariva et al., 2013) and the apparently space segregation between those species (Cassemiro et al., 2005) can cause changes in diet, due, for example, to the lack of preferential resource or competition. According to Agostinho et al. (1999), areas upstream from reservoirs are the least affected by dams. In fact, this trend was observed in this study, but still must be considered that the changes were relevant. Therefore, increments in the condition factor in other sites more affected should be evaluated with caution, as they seem more influenced by interannual variables than properly by damming. Thus, if the increase in the upstream site (UP), which is less affected, is considered as a reference and increases verified in the other sites could be, in fact, a reduction in the condition factor.

Hoplias aff. malabaricus, $O$. longirostris and $P$. britskii, had previously, to a greater or lesser extent, consumed a remarkable amount of fishes, being favoured in an environment where this resource became abundant. As a result, they increased the condition factor after damming. For $A$. lacustris, this decrease was evident in all of the sites, being more pronounced in those where the diet changes were higher, independent of the feeding intensity. It can be considered that changes to a piscivorous diet for A. lacustris, despite its high protein and energy content and easy digestion, can result in worsening nutritional status.

Astyanax lacustris presented a great increase in abundance despite the observed decrease in condition factor. This is probably connected to the opportunistic reproductive strategy of this species, which possesses a good colonizing ability when facing unpredictable environmental variations (Winnemiller, 1989) being capable of population growth despite the condition factor. Therefore, this low nutritional status can make long term maintenance unsustainable if the species continues on the considered diet. Cassemiro et al. (2005) observed that this 
species returned to a herbivorous diet three years after the reservoir was formed, which may explain the maintenance of a large population in the dammed environment.

It is clear that specialist piscivorous fish will benefit in the early years after damming, mainly because of the increase in fish prey, resulting in better nutritional state and population growth, while for those opportunistic species morphological features will determine if the species will or not have long term advantages in the diet changes, and, for those species that do not possesses such morphological adaptations maintain the large populations, changes to the previous feeding habit will be required.

\section{Acknowledgements}

We thanks Nupélia team (Núcleo de Pesquisas em Limnologia, Ictiologia e Aquicultura) for the database, biological material and lab facilities and Luiz Carlos Gomes and two anonymous referees for reviewing earlier version of the manuscript and provide valuable contributions. Daniel Fitzgerald for English revision and Norma S. Hahn for suggestions. CAPES (Coordenação de Aperfeiçoamento de Pessoal de Nível Superior) provided a scholarship for LSP and CNPq provided a research grant for AAA.

\section{References}

Abelha, M. C. F., A. A. Agostinho \& E. Goulart. 2001. Plasticidade trófica em peixes de água doce. Acta Scientiarum, 23: 425434.

Abelha, M. C. F., E. A. L. Kashiwaqui \& E. Goulart. 2012. Population structure, condition and diet of Oligosarcus paranensis (Menezes \& Gery, 1983) (Osteichthyes: Characidae) at two reservoirs in South Brazil. Biota Neotropica, 12: 187-197.

Agostinho, A. A., L. E. Miranda, L. M. Bini, L. C. Gomes, S. M. Thomaz \& H. I. Suzuki. 1999. Patterns of colonization in neotropical reservoirs, and prognoses on aging. Pp. 227-265. In: Tundisi, J. G. \& M. Straskraba (Eds.). Theoretical reservoir ecology and its applications. São Carlos: International Institute of Ecology (IIE); Leiden, Netherlands: Backhuys.

Agostinho, A. A., F. M. Pelicice \& L. C. Gomes. 2008. Dams and the fish fauna of the Neotropical region: impacts and management related to diversity and fisheries. Brazilian Journal of Biology, 68: 1119-1132.

Ahlbeck, I., S. Hansson \& O. Hjerne. 2012. Evaluating fish diet analysis methods by individual-based modelling. Canadian Journal of Fisheries and Aquatic Sciences, 69: 1184-1201.

Anderson, M. J. 2006. Distance-based tests for homogeneity of multivariate dispersions. Biometrics, 62: 245-253.

Anthony, J. A., D. D. Roby \& K. R. Turco. 2000. Lipid content and energy density of forage fishes from the northern Gulf of Alaska. Journal of Experimental Marine Biology and Ecology, 248: 53-78.

Árnason, T., B. Björnsson \& A. Steirnarsson. 2009. Allometric growth and condition factor of Atlantic cod (Gadus morhua) fed to satiation: effects of temperature and body weight. Journal of Applied Ichthyology, 25: 401-406.
Baumgartner, G., C. S. Pavanelli, D. Baumgartner, A. G. Bifi, T. Debona \& V. A. Frana. 2012. Peixes do baixo rio Iguaçu. Maringá, Eduem, 203p.

Bennemann, S. T., W. Galves \& L. G. Capra. 2011. Recursos alimentares utilizados pelos peixes e estrutura trófica de quatro trechos no reservatório Capivara (rio Paranapanema). Biota Neotropica, 11: 63-72.

Casatti, L., F. Langeani \& R. M. C. Castro. 2001. Peixes de riacho do Parque Estadual Morro do Diabo, bacia do alto rio Paraná, SP. Biota Neotropica, 1: 1-15.

Cassemiro, F. A. S., N. S. Hahn \& R. L. Delariva. 2005. Estrutura trófica da ictiofauna, ao longo do gradiente longitudinal do reservatório de Salto Caxias (rio Iguaçu, Paraná, Brasil), no terceiro ano após o represamento. Acta Scientiarum Biological Sciences, 27: 63-71.

Davis, N. D., K. W. Myers \& Y. Ishida. 1998. Caloric value of high-seas salmon prey organisms and simulated salmon ocean growth and prey consumption. North Pacific Anadromous Fish Commission Bulletin, 1: 146-162.

DeAngelis, D. L., R. A. Goldstein \& R. V. O’Neill. 1975. A model for trophic interaction. Ecology, 56: 881-892.

Delariva, R. L., N. S. Hahn \& E. A. L. Kashiwaqui. 2013. Diet and trophic structure of the fish fauna in a subtropical ecosystem : impoundment effects. Neotropical Ichthyology, 11: 891-904.

Delariva, R. L., N. S. Hahn \& L. C. Gomes. 2007. Diet of a catfish before and after damming of the Salto Caxias reservoir, Iguaçu River. Brazilian Archives of Biology and Technology, 50: 767-775.

Dill, L. M. 1983. Adaptative flexibility in the foraging behavior of fishes. Canadian Journal of Fisheries and Aquatic Sciences, 40: 398-408.

Dytham, C. 2011. Choosing and using statistics: a biologist's guide. $3^{\text {rd }}$ ed. Wiley-Blackwell, 298p. Hoboken, NJ.

Fernando, C. H. \& J. Holčík. 1991. Fish in reservoirs. Internationale Revue der gesamten Hydrobiologie und Hydrographie, 76: 149-167.

Gomes, L. C. \& A. A. Agostinho. 1997. Influence of the flooding regime on the nutritional state and juvenile recruitment of the curimba, Prochilodus scrofa, Steindachner, in upper Paraná River, Brazil. Fisheries Management and Ecology, 4: 263274.

Gubiani, E. A., R. Angelini, L. C. G. Vieira, L. C. Gomes \& A. A. Agostinho. 2011. Trophic models in Neotropical reservoirs: testing hypotheses on the relationship between aging and maturity. Ecological Modelling, 222: 3838-3848.

Gubiani, É. A., L. C. Gomes \& A. A. Agostinho. 2009. Lengthlength and length-weight relationships for 48 fish species from reservoirs of the Paraná State, Brazil. Lakes \& Reservoirs: Research \& Management, 14: 289-299.

Hahn, N. S., A. A. Agostinho, L. C. Gomes \& L. M. Bini. 1998. Estrutura trófica da ictiofauna do reservatório de Itaipu (Paraná - Brasil) nos primeiros anos de sua formação. Interciência, 23: 299-305.

Hahn, N. S. \& R. Fugi. 2007. Alimentação de peixes em reservatórios brasileiros: alterações e conseqüências nos estágios iniciais do represamento. Oecologia Brasiliensis, 11: 469-480

Hahn, N. S. \& R. Fugi. 2008. Environmental changes, habitat modifications and feeding ecology of freshwater fish. Pp. 36-65. In: Cyrino, J. E. P., D. P. Bureau \& B. G. Kapoor (Eds). Feeding and digestive functions of fishes. Enfield, NH, Science Publishers. 
Hellawell, J. M. \& R. Abel. 1971. A rapid volumetric method for the analysis of the food of fishes. Journal of Fish Biology, 3: 29-37.

Hyslop, E. J. 1980. Stomach contents analysis - a review of methods and their application. Journal of Fish Biology, 17: 411-429.

Kimmel, B. L. \& A. W. Groeger. 1986. Limnological and ecological changes associated with reservoir aging. Pp. $103-$ 109. In: Hall, G. E. \& M. J. Van Den Avyle (Eds.), Reservoir fisheries management: strategies for the $80^{`} \mathrm{~s}$. Bethesda, Maryland, American Fisheries Society.

Le Cren, E. D. 1951. The length-weight relationship and seasonal cycle in gonad weight and condition in the perch (Perca fluviatilis). Journal of Animal Ecology, 20: 201-219.

Lima, S. L. 1998. Nonlethal effects in the ecology of predatorprey interactions: what are the ecological effects of antipredator decision-making? BioScience, 48: 25-34.

Loureiro-Crippa, V. E. \& N. S. Hahn. 2006. Use of food resources by the fish fauna of a small reservoir (rio Jordão, Brazil) before and shortly after its filling. Neotropical Ichthyology, 4: 357-362.

Lucena, C. A. S. \& H. G. Soares. 2016. Review of species of the Astyanax bimaculatus "caudal peduncle spot" subgroup sensu Garutti \& Langeani (Characiformes, Characidae) from the rio La Plata and rio São Francisco drainages and coastal systems of southern Brazil and Uruguay. Zootaxa, 4072: 101-125.

Luz-Agostinho, K. D. G., L. M. Bini, R. Fuji, A. A. Agostinho \& H. F. Júlio Jr. 2006. Food spectrum and trophic structure of the ichthyofauna of Corumbá reservoir, Paraná river Basin, Brazil. Neotropical Ichthyology, 4: 61-68.

Nikolsky, G. V. 1963.The ecology of fishes. Translated from the Russian by L. Birkett. London: Academic Press, 352p.

Novak, M. \& J. T. Wootton. 2008. Estimating nonlinear interaction strengths: an observation-based method for species-rich food webs. Ecology, 89: 2083-2089.

Novakowski, G. C., N. S. Hahn \& R. Fugi. 2007. Alimentação de peixes piscívoros antes e após a formação do reservatório de Salto Caxias, Paraná, Brasil. Biota Neotropica, 7: 149-154.

Nowlin, W. H., R. W. Drenner, K. R. Guckenberger, M. A. Lauden, G. T. Alonso, J. E. Fennel \& J. L. Smith. 2006. Gape limitation, prey size refuges and the top-down impacts of piscivorous largemouth bass in shallow pond ecosystems. Hydrobiologia, 563: 357-369.

O'Brien, W. J. 1990. Perspectives on fish in reservoir limnology. Pp. 209-225. In: Thornton, K. W., B. L. Kimmel \& F. E. Payne (Eds.). Reservoir limnology: ecological perspectives. New York, J. Wiley.
Oksanen, J., F. G. Blanchet, R. Kindt, P. Legendre, P. R. Minchin, R. B. O'Hara, G. L. Simpson, P. Solymos, M. H. H. Stevens \& H. Wagner. 2015. Vegan: community ecology package: ordination, diversity and dissimilarities. Version 2.3-0. Available from: http://CRAN.R-project.org/package=vegan

Orsi, M. L. \& J. R. Britton. 2014. Long-term changes in the fish assemblage of a neotropical hydroelectric reservoir. Journal of Fish Biology, 84: 1964-1970.

Pacheco, A. C. G., R. Bartolette, J. F. Caluca, A. L. M. de Castro, M. P. Albrecht \& É. P. Caramaschi. 2009. Dinâmica alimentar de Rhaphiodon vulpinus Agassiz, 1829 (Teleostei, Cynodontidae) no alto Rio Tocantins (GO) em relação ao represamento pela UHE Serra da Mesa. Biota Neotropica, 9: $77-84$.

Peretti, D. \& I. F. Andrian. 2008. Feeding and morphological analysis of the digestive tract of four species of fish (Astyanax altiparanae, Parauchenipterus galeatus, Serrasalmus marginatus and Hoplias aff. malabaricus) from the upper Paraná River floodplain, Brazil. Brazilian Journal of Biology, 68: 671-679.

Rooney, N., K. McCann, G. Gellner \& J. C. Moore. 2006. Structural asymmetry and the stability of diverse food webs. Nature, 442: 265-269.

Santos, C. M., S. Duarte, T. G. L. Souza, T. P. Ribeiro, A. Sales \& F. G. Araújo. 2007. Histologia e caracterização histoquímica do tubo gastrintestinal de Pimelodus maculatus (Pimelodidae, Siluriformes) no reservatório de Funil, Rio de Janeiro, Brasil. Iheringia, Série Zoologica, 97: 411-417.

Schmitz, O. J. 1992. Exploitation in model food chains with mechanistic consumer-resource dynamics. Theoretical Population Biology, 41: 161-183.

StatSoft, Inc. 2011. STATISTICA (Data Analysis Software System), version 10. www.statsoft.com.

Van Der Meer, J., \& B. J. Ens. 1997. Models of interference and their consequences for the spatial distribution of ideal and free predators. Journal of Animal Ecology, 66: 846-858.

Vazzoler, A. E. A. de M. 1996. Biologia da reprodução de peixes teleósteos: teoria e prática. Maringá, EDUEM; São Paulo, SBI, 169p.

Winemiller, K. O. 1989. Patterns of variation in life history among South American fishes in seasonal environments. Oecologia, 81: 225-241.

Zavala-Camin, L. A. 1996. Introdução aos estudos sobre alimentação natural em peixes. Maringá, Eduem, 1996, 129p.

Submitted May 10, 2015

Accepted December 03, 2015 by Franco Teixeira de Mello 